\title{
PARTICIPAÇÃO POLÍTICA E USURPAÇÕES POLÍTICAS: 0 ENFRAQUECIMENTO DOS DIREITOS HUMANOS POR SUAS ABORDAGENS IDEOLÓGICAS
}

\author{
POLITICAL PARTICIPATION AND POLITICAL USURPATIONS: THE WEAKENING \\ OF HUMAN RIGHTS BY THEIR IDEOLOGICAL APPROACHES
}

\section{Mártin Perius Haeberlin}

Doutorado em Direito pela Pontifícia Universidade Católica do Rio Grande do Sul PUCRS (2014). Mestrado em Direito do Estado - PUCRS (2006). Pós-Doutorado em andamento em Economia pela Universidade Federal do Rio Grande do Sul UFRGS, Professor da Graduação e do Programa em Pós-Graduação Stricto Sensu em Direitos Humanos do Centro Universitário Ritter dos Reis - UniRitter.

\section{João Paulo Kulczynski Forster}

Doutorado em Direito pela Universidade Federal do Rio Grande do Sul - UFRGS (2015). Mestrado em Direito pela UFRGS (2011). Docente da Graduação e do Programa em Pós-Graduação Stricto Sensu em Direitos Humanos do Centro Universitário Ritter dos Reis - UniRitter .

\begin{abstract}
Resumo
O presente artigo propõe o entendimento da participação política não apenas como um fenômeno ideológico, mas também como um direito originado das Constituições. Para explorar essa ideia, notadamente no contexto da recente experiência política dos países latino-americanos, incluindo o Brasil, realiza-se uma separação entre Direito Constitucional e ideologias, considerando a presença destas em diversos espaços, dentre os quais a interpretação dos direitos humanos e fundamentais. Para alcançar esse objetivo, em um primeiro momento são demonstrados o conteúdo e as características das ideologias. Depois, oferece-se uma distinção entre ideologias em sentido forte e fraco. Por fim, propõe-se um mecanismo para separar a participação política das concepções ideológicas em prol de uma abordagem constitucional, em cujo contexto a participação política é apresentada como um mandamento de "não-egotopia" segundo o qual, sendo as pessoas fundantes da Constituição, delas demanda a normatividade que advém de seu texto.
\end{abstract}


Palavras-chave: Egotopia. Ideologia. Direitos humanos. Participação política.

\begin{abstract}
The present essay proposes understanding political participation not only as an ideological phenomenon, but also as a right originated from the Constitutions. To explore this idea, notably in the context of recent political experience in Latin American countries, including Brazil, the separation of Constitutional Law and ideologies is addressed, considering they have impregnated several spaces, among which the interpretation of human and fundamental rights. In order to achieve this objective, first the content and characteristics of ideologies is demonstrated. Then, a separation of ideologies in a strong and weak sense is offered. Finally, a mechanism is proposed to separate political participation from ideological conceptions towards a constitutional approach in which political participation is presented from a requirement of non-"egotopia", arguing that while people are the foundation of the Constitution, they demand the normativity that comes from its text.
\end{abstract}

Keywords: Egotopia. Ideology. Human rights. Political participation.

\title{
1. INTRODUCTION
}

Political participation is both the transmitter and the receiver of collective ideas. It is usual to perceive it as an ideological phenomenon, not as a right originated from the Constitutions that abide by the Rule of Law.

Recent experience in Latin American countries, especially in Brazil, let us think that ideologies have crossed their line, abandoning politics to enter the legal system, including all judicial activity, from lower courts to the Supreme Court itself. In that context,political participation seems to be absorbed in the arena of ideological debates pervading various spaces, among which the interpretation of fundamental and human rights ${ }^{1}$. In other words: political participation may have become political usurpation.

It is quite clear that this phenomenon is not restricted to the aforementioned Latin American Countries, as it represents a perspective that it proves itself to be

\footnotetext{
1 The argument elaborated in this article dismisses the distinction between human and fundamental rights, since the phenomenon mentioned occurs for both.
} 
valid in other parts of the modern world.It only proves itself to be more easily detected in those countries due to a "second wave of constitutionalisation" (GARGARELLA, 2014, p. 13) in countries like Brazil, Colombia, Venezuela, Ecuador and others.

Assuming the premise that law (thinking about the normative model set by principles and rules) is connected to ideologies, the present essay seeks to understand such connection and dismember it in order to demonstrate political participation as a constitutional right. That effort is based on the separation between weak and strong ideologies. Afterwards, a mechanism is proposed to separate political participation from ideological conceptions in favor of a constitutional approach in which this issue is presented from a requirement of "non-egotopia" (HAEBERLIN, 2017, p. 285-293).

The challenge of placing political participation vis-à-vis the notion of egotopia is addressed as strong claim of the people - from who all power emanates - for their human and fundamental rights. Not where people are the majority nor the minority,but where people are the foundation of the Constitution (ISENSEE, 1995) and, therefore, require the regulations that come from its text.

In a sense, this is a study of persons and their interests. As rights arise from interests and their protection, "interests are constitutive of the human being as a person" (GRIMM, 1991, p. 176). Indeed, interests take on a role of extreme relevance for the law. In order to agree or disagree with Michel de Montaigne, when he said that "laws sustain their credit not because they are just, but because they are laws" (MONTAIGNE, 1565), we are obliged to ask: in the absence of a transcendent foundation, what makes laws laws? The question leads to a conclusion: interests.

Considering individuals as concrete persons, not as abstract entities, it is not difficult to establish that the question of interest, more properly of plurality of interests, is presupposed to the problems related to political participation. To think about political participation of the most diverse communities is to think about legal answers for the multiplicity of personal interests.

The search for legal answers to these problems (as opposed to the responses submitted to the winds of ideologies) goes not only through recognizing the effective burden of principles and rules - otherwise already consolidated in contemporary law - but also through inserting political participation in that space of 
principles and rules. In other words: regarding political participation in constitutional terms. It is necessary, then, assuming the model of rules, since Ronald Dworkin is sound in the legal doctrine, to show how political participation is usually understood from an ideological bias instead of originated from the constitutional structure, based on principles and rules.

In the past five years, having experimented diverse popular manifestations (like the protests of June 2013) and an impeachment process of a President, Brazil has become an interesting laboratory to think about this theme. Latin America has also become an interesting laboratory, especially with the changing flow of ideologies which havebeen taking power in the countries that made them, sometimes with right and left-winged radicalizations.

So, we must understandthat political participation does not sum up to legal responses, but to ideological effects which must also be understood.

\section{CONTENT AND CHARACTERISTICS OF IDEOLOGIES}

The word praxis (ாрá£ı) has a Greek origin, meaning a human activity in which the activity itself and its product are inseparable. The word, however, is traditionally remembered from the conception of a "philosophy of praxis" elaborated by Karl Marx and Friedrich Engels and, later, Antonio Gramsci, especially in his referential studies about ideology. And here the reason for explaining ideologies as praxis appears. Ideologies use theoretical understandings of the social fabric to impregnate the very object of their studies. It is, therefore, a behavior that moves away from thinking about the search for material realization of thought, involving and transforming its object.

This sense of praxis marks the "interpreting / transforming" dichotomy pointed out by Marx and Engels in the famous XI Thesis on Feuerbach, when stated that the philosophers until then hardly interpreted the world, while the question imposed was to transform the world. (ENGELS, 1845)

The "philosophy of praxis" was a critique of ideology - of bourgeois ideology or, if one prefers, ideology of the status quo. But the movement of criticism of ideologies, precisely because ideology is praxis, tends to produce contrary ideologies. Put in check an ideology, and it is opposed to another. For example, the "Marxist ideology", whose theoretical scope was the presentation of history as the 
history of "class struggle" (MARX e ENGELS, 2002, p. 23), whose plan of material realization was the revolution of the oppressed and alienated class (the proletariat).

Notwithstanding the reference to ideology as praxis brought to us straight from Marx and Engels, there is a theoretical source, previous and subsequent to that referential which is convenient to rescue, albeit in a tight historical synthesis. ${ }^{2}$

Historically, the term "ideology" was coined by Destutt de Tracy, in a book published in 1801 entitled Elémentsd'Idéologie. It took on a different meaning from the one we use today. It was about the pretension to elaborate a genealogy of ideas, constructed from a theory of the sensitive faculties apt to relate the human body and the environment. From modern rationality, the ideology of De Tracy (followed by Cabanis, De Gérando and Volney), on one hand, presented a critique of metaphysical conceptions of knowledge, especially theological ones, and, on the other, set a new pedagogy and a new moral inadequate to the Ancien Régime. This ideology united them with Napoleon Bonaparte in the coup of 18 Brumaire, a union that did not last long because people were disappointed with the characteristics of the Napoleonic government, similar to the one they fought. From the rupture, more precisely from a discourse of Napoleon against the "ideologues", came the pejorative sense of the term.

Auguste Comte rescued the term in his Cours de Philosophie Positive (the first of the six volumes was published in 1830) presenting alongside that sense of formation and genealogy of ideas created by De Tracy, the meaning of a set of ideas of an epoch, which, originated in the current opinions, are organized, systematized and corrected by thinkers, whose responsibility is the transformation of their theological or metaphysical spirit into a scientific or positive spirit.

The term would be taken up again in its pejorative sense in Les règles de la méthodesociologique (1895), by Émile Durkheim. Sociology, according to the author, in the purpose of studying society and healing their pathologies, should be operated by a method whose rules would allow sociologists, in a neutral and objective way, to separate the subject of knowledge (sociologist) from the object of knowledge (social facts) in the same way that scientists investigate the phenomena of nature. Durkheim calls ideology, and hence its pejorative nature, all knowledge of society that does not

\footnotetext{
2 This historical investigation was contributed from four references: ARENDT, 1962; POPPER, 1987; CHAUÍ, 1984; and SEVERINO, 1986.
} 
respect the rules of the sociological method.

If it is true that the question of ideology reverberated later in various schools and authors, such as Karl Mannheim, Max Weber, Paul Ricoeur, GyörgyLukács, and in the "critical theory" of the Frankfurt School, with the works of Herbert Marcuse, Walter Benjamin, Theodor Adorno, Max Horkheimer and Jürgen Habermas, it is also true that the most important and embryonic ideology witnessed in the twentieth century, at least in the sense of a "civil religion", was undoubtedly Marxism. Marx died, just as, since the fall of the Berlin Wall, and - perhaps hastily and without verification of the death certificate -the death of communism was declared.

If our exposition begins with Marx, the natural question is about whether the 21 st century, of which the very first mid-years were lived, is or will also be pregnant with revolutions under ideological signs.

The answer, even hypothetically, seems to indicate the false paradox of a "no" followed by "and yes". The paradox is solved by dividing the answer in terms of form, where the answer seems "no", and in terms of content, where the answer is then complemented.

In terms of form, that is, the revolutionary way as ideologies and counterideologies emerged, it seems that the near future of societies tends to restrain their birth. ${ }^{3}$ That happens because, from the point of view of form, ideologies, when initially revolutionary, tend to convalesce against omnipresent commandments of the contemporary Constitutions and against the coercion mechanisms of International Law erected exactly against what was done in the past on their behalf; when initially non-revolutionary, they tend to be sheltered in pluralism based on those same Constitutions and, therefore, without a propensity for revolution.

As for the content, the same cannot be said. Revolution is not the substance of ideology. Its substance is the imperfections intimate to the existence of man in social plurality. "Ideology is an insurmountable phenomenon of social existence, insofar as social reality always has a symbolic constitution and involves an interpretation, in images and representations, of one's social bond." (RICOEUR, 1977, p. 75)

Ideologies, reflecting the existence of man himself, will continue to exist, just

\footnotetext{
${ }^{3}$ The argument presented here has an abode in the Democratic States of Law. Do not neglect, however, the revolutionary movements occurred recently, occurring nowor which may occur, especially in the East (as in Morocco, Egypt, Tunisia, Libya, Algeria, among others) and in the West, especially in America Latina, as at present in Venezuela).
} 
like birds that seek flight after losing their nest in a storm tend to make a new nest in which they can land. From the legal point of view, which interests us in this essay, there seem to be two places to land. A benefic one, which is the space within the constitutional order and which reserves a nest to each and every one of the ideologies, and a harmful one, which is the space outside the constitutional order where ideologies act like the cowbird, leaving their eggs in other people's nests, forcing other birds to hatch and raise their young. ${ }^{4}$

\section{3. DISTINCTION BETWEEN "WEAK" IDEOLOGY AND "STRONG" IDEOLOGY}

Approaches that link law and ideology are well-known. We start from this premise: they are, in fact, inseparable. The following problems, however, are raised as the object of our analysis: (i) what kind of ideology is the law linked to (or should it be linked to) and how should that connection be operated; (ii) how law and ideology are separated (or should be separated) ${ }^{5}$

To answer the first question, we recall that two types of ideologies are often differentiated, and although they are mentioned in more diverse names, the terms "strong" and "weak" have been adopted here, because they are thought to be more representative than the others.

The weak ideology is that apprehended by the sociology of knowledge. It means understanding different currents of thought when abstracting moral and political intentions in the sense of action. This is the kind of ideology whichMarilenaChauí conceptualizes - after emphasizing that ideologies are not subjectivities, preconceptions or false ideas - as "a certain way of producing ideas by society, or rather, by certain historical forms of social relations." (CHAUÍ, 1984, p. 31)

The strong ideology is the illusory representation woven in the society, impregnated by shield interests aiming at domination;therefore, in favor of particular interests. Such a meaning is represented by the Marxist conception of ideology, summarized in the exposition of ideology as "the use of thinking activity as a resource

\footnotetext{
${ }^{4}$ On the "mafia behavior" of these birds, in the sense of forcing their victims (other birds) to hatch eggs and raise their offspring under the threat of destruction of "legitimate" eggs, see: HOOVER and ROBINSON, 2007.

${ }^{5} \mathrm{We}$ will address the first question in this topic and at the latter in the next one.
} 
of dominion." (SEVERINO, 1986, p. 9).And it is also represented by neoliberal ideology, as denounced by Paulo Freire: "The ability to put a penumbra in reality, to leave me short-sighted, deaf to ideology makesmany of us, docile in accepting a cynically fatalistic neoliberal discourse which proclaims unemployment in the world as a misfortune of the end of the century." (FREIRE, 2002, p. 142) This type of ideology is a deleterious brand pushed in various academic debates, as testified by Ernildo Stein: "with Gadamer, I freed myself from the straitjacket of the ideological debate which has poisoned many heads in Brazil."6

With regard to the types of ideologies and in response to the question that we began to answer, it can be noted at first (the moment of the constitutional politics)that the law is linked to both. However, at a later time, it endorses only ideology in the weak sense, as expressed in the Constitution.

Indeed, while the law is still a political stage (therefore, from a positivist conception, a right is an "act of will" $)$, it must deal with the formation of a consensus in the constitutional order, where ideologies in the weak and strong sense are present. Operated by the consensus, it will present itself as presence of difference. (RAWLS, 1999) Something out of the whole is incorporated into the constitutional text. This, in the filling and void of his words - as in the silence of an aria sometimes integrates the melody -, combines the political elements underlying democracy. In other words, the "will to power" - Wille zurMacht (NIETZSCHE, s.d) - of the singular is partialized to unfold in the part of plurality which admits coercion.

It is in order to preserve the difference that the constitutional text forces itself. The bias of Constitution makes its text, therefore, a "product of substantive commitments", which translates into an effort to replace the legacy of sovereignty based on authority by a republic of reasons. (SUNSTEIN, 1993, p. 8 and 347)

Once consensus has been reached, no ideology, strong or weak, can use its own commitment as Shakespeare's merchant: as an artifice for non-fulfillment. Neither because ideologies themselves have helped to shape, ending in it, nor by the fact of a hollow respect to that founding generation, but by the fact that this is the instrument astringing the voice of allreasons in a republic of reasons. In the end, the

\footnotetext{
${ }^{6}$ Thissentencewasheardfroman interview transcriptionat: <http://www.ajaxme.com/gratis/novidadesweb/ernildo-stein-uma-ponte-entre-a-consciencia-e-o-mundo>. Acesso em 15 jul. 2016.

7 It is the so-called "social thesis", accepted as a central thesis among the most diverse positivist conceptions. On the subject, see, among others: COLEMAN, 1999, p. 241-59.
} 
question of Laurence Tribe and Michael Dorf, about whether the Constitution is only a mirror in which everyone sees only what they want, (TRIBE; DORF, 1991, p. 6) deserves a negative answer.

Obviously, that astringency uniting plural ends in the north of a Constitution is not perfect for everyone. A central problem begins here, the so-called "Madison dilemma", which consists of reconciling two antagonistic principles: self-government, referring to the right given to majorities to govern, justified by the fact of being a majority; and the restrictions of majority powers against minorities. ${ }^{8}$

However, since it has maintained the legal system created by the Constitution, the only possible solution is to preserve its structure, competence, and authority. In the republic of reasons, the Constitutional Court, as guardian of the Constitution, constitutes an argumentative representation of the citizen.

This is the last step for the answer to the first problem formulated: the relation between the Constitution and the two types of ideology at the time after the constitutional policy.

Exceeding politics, in which strong and weak ideologies are somehow sublimated in the Constitution, it is imperative that ideologies in the strong sense be eradicated, since in the power toys they perform in favor of private interests,they implore the public interest, without which the Constitutions lose meaning.

Strong ideologies, therefore, have surpassed the moment of politics, they are in a place outside the Constitution (constitutional aside). Weak ideologies, on the other hand, deserve constant attention of law, since, of course, they are transposed into constitutional grammar. In fact, attention will not be given to them, therefore, as ideologies, but as a Constitution (constitutional inside).

What is sought after with these divisions is a "reading ethics" which a priori, if there is, is the a priori of a non-classical transcendental. The a priori of the principles forms the most rigid core of a Constitution: its human and fundamental rights. It is worth emphasizing: that nucleus cannot be transcended by any ideology, except when these ideologies are, themselves, Constitution.

It cannot be denied, therefore, that ideologies play an important role within and outside the Constitution, especially in two areas: that of constitutional interpretation and that of constitutional mutations. On the contrary, it acknowledges

\footnotetext{
8 The exhibition on Madison's dilemma and its confrontation is a synthesis of: BORK, 1993.
} 
value to the facts that: (a) the Constitutional Court is a political power; (b) the Constitution incorporates a Living Constitution conception which prints new readings to ancient texts; (c) the constitutional text is an "open texture"; (d) the Constitution itself is open, with society also acting as an interpreter; and (e) the judge, as a qualified interpreter by the order to give final answers, or as an authentic interpreter, as Kelsen wanted, retains its ideologies in a biography that affects the subsumption.

Although these truths were invigorated over the last century, in the realm of the Theory of Law and Constitutional Law, it is believed that it is possible, now and always, to endorse a conclusion drawn from classical hermeneutics: "the function of the judge, in terms of texts, is to dilate, complete and understand; but not to change, correct, replace. (...) everything seeks to find and resolve with the law; never with the uncovered intention of acting on their own, praeter or contra legem." (MAXIMILANO, 2005, p. 65)

In regard to reading past texts within a present outlook, we believe that the above jurist would have accepted to replace the term "with the law" for "with the Constitution." The same he would not do, we speculate, for the expression "with a right found in the streets or anywhere"?.

\section{THE COMMANDMENT OF NON-EGOTOPIA: AVOIDING IDEOLOGICAL CONCEPTIONS}

Political participation was exposed as a right, conformed by principles and rules. The theory of ideology was also exposed, recalling its praxis character, proposing the division between weak and strong ideologies and their consequences for Constitutional Law.

Our purpose now is to answer the second question: how do law and ideology separate (or should be separated)? The proposal of this essay is carried out here: to de-ideologize the right of constitutional characteristics: in other words, to separate political participation from the egotopiawhich usually accompanies it.

A two-way problem presents itself. On the one hand, it addresses the need for recognition, by majorities, of diversity as a constituent of the State. At that point, it is directed to the aforementioned "Madison's dilemma". On the other hand, the

\footnotetext{
${ }^{9}$ The theory of "law found in the street" could be seen in: LYRA FILHO, 1993, p. 55-60.
} 
problem addresses the need for recognition, by majorities and minorities, of a sense of justice as a constituent of the State.

This last point refers to the so-called "reflective equilibrium". Such balance leads to the idea that, in the consideration of their guidelines, individuals and groups seek a less self-interested and more reasonable position. It takes into account the fact that state actions must be justified to all citizens, as required by the principle of political legitimacy. (RAWLS, 1996, p. 224)

Once the collision of fundamental rights, a true contingency of plural societies in the context of an "open plot" of the principles, allows various possible interpretations, we are faced with a moral problem. The embezzlement of normative interpretations. Unreasonable individuals and groupsrelativize some principles in the intent of making the constitutional "open plot" a one-way street.

Such behavior can be designated as "egotopian" (HAEBERLIN, 2017). Egotopia refers to a "place" (topos) where one wants to find only himself (ego). An "egotopia" would, therefore, be the "place of myself". Egotopia is the constant attempt to extend the "place of myself" to all possible spaces, public and private, in a movement which neglects the space of others. ${ }^{10}$ The expression designates, therefore, a way of looking at the Constitution in which it is a mirror of one's own demands (individual or collective), and where the compatibility of its reading with the social whole is forgotten.

The problem of egotopia arises exactly when the constitutional principles and the discourses related to them - leave the juridical plane and gain a dwelling place in ideologies.

In the social bond, a common origin of principles and ideologies is found. However, in the light of the assumption that principles and rules continue indefinitely in the system, while ideologies after the Constitution live on its side, we understand that it is possible to de-ideologize the constitutional principles. This is possible by pointing out the similarities between principles and ideologies summarized in five characteristics: (i) regarding the behavior in the system (if principles are arché, ideologies are práxis); (ii) regarding the form of action (if principles are legal norms, ideologies are social orientations); (iii) regarding the purpose of action (if principles establish the search for a state of affairs and limits to the action of the State,

10 Peter Koller (2002, p. 53), embracing that sense, speaks in a "selfishness of groups" (Gruppenegoismus). 
ideologies establish deep-rooted links); (iv) Regarding the formation of consensus (if principles are formed from consensus and establish, from it, provisions, ideologies seek to impose positions, regardless of consensus); and (v) regarding the logic of the discourse (if principles are carried out in the weighting, ideologies work with imponderable arguments).

De-ideologization is a kind of people's defense in relation to state action, prohibiting the transformation of political participation into egotopia. And that is absolutely necessary, once, together with the discourse of norms as principles, we testify to a kind of "ideology of human rights", that is, an egotopia production of human (and fundamental) rights. It deals with the interpretation of human rights from exclusionary conceptions, provided by political or social groups with an identifiable matrix, usually rooted in so-called minorities. These groups, defending "causes" (ideological) instead of arguments (constitutional), capitulate rights from a project of power, with guidelines and standardized behavior, whose objective prevails, by dogmatic imposition, especially the legal system. (HAEBERLIN, 2017)

In these egotopian productions, human and fundamental rights turn into a battlefield, where the force of arguments is replaced by the force of convictions. They impose on society, using as a showcase the reverse of the product of their conquests (instead of the very conquests). In this criticism, a human rights study dissociated from the content of human rights emerges. A kind of totalitarianism (unspoken, impregnated and scathing) that hijacks the fundamental principles of the constitutional order and makes them hostages for purposes that, even when high, are, in reality, spurious of the democratic demand on which the Constitution is based. ${ }^{11}$

The space of reasoning is exactly the field in which political participation gains density and from which it must be thought,hence evoking the concept of "reflective equilibrium", developed by Rawls and synthesizable in the idea of weighing several proposed conceptions.

We could say, in view of the concept, that the understanding of political participation compatible with the public interest (which departs from egotopia) goes through three stages.

\footnotetext{
11 It is observed, still and once again, that the criticism referred to here and the very conception of democracy is valid "beyond left and right", to use the expression of:GIDDENS, 1994.
} 
The first stage is the search for reflexive equilibrium, where aprioristic and chunked thoughts must be rejected, that is, those whose result is already known before the weighting and the corresponding motivation. In the search for reflective equilibrium, the question that must haunt defenders of the rights of specific communities (such as religious, rural, African American, Indian, women, gay, children, the elderly, etc.), is: "how can we insert our schedule in the notion of the common good of society in general?" and not the one that recurrently appears, which is "how can we transform the notion of common good of society in general into our schedule?". The first question makes the notion of the common good gain density (and generate an effective political participation). The second question, strangles the notion (and produces no more than egotopia).

The second stage, not being able to make a consensus decision for specific issues, after reflective equilibrium, involves finding means so that conflicting views about a given object can coexist in different spaces. To understand that it is necessary to understand that there are social spaces of exclusion (provided they are private), and that this does not cripples the idea of justice of a society. On the contrary, it consecrates it in pluralism. This is because different communities are linked to different values. For that reason, part of the reflexive balance is to reject the intrusion of values in a community, provided that the object of that community is not to harm the values of others. Any introjection of values, from one community to another, is a kind of moral violence. A position of "non-belonging" is sought at that stage. It would be an example of moral violence to force a priest of the Catholic Church to celebrate a gay marriage. This couple must understand that it does not belong, at least for that matter, to that community, and thus respect the values of that community. However, this should not mean the impossibility of acknowledging this marriage. Both the introjection of values of the Church to the couple, and of the couple to the Church, are species of moral violence, which do not pass the second stage of reflective equilibrium.

The third stage is exception. That is, when consensus is not obtained in reflective equilibrium in a certain community, in its object or form of action, it causes damage to the values and rights of another. It would be the example of Christian communities seeking to prevent gay marriage not only in their Church, but in the public space. In that case, the state action must protect the values achieved although it must act by vertical imposition. 
Political participation gains its necessary "density" in the social fabric operated in these three stages. With them, it is possible to advocate a non-egotopian order, thus constituted: "all state action must be based on reflective equilibrium, avoiding obtuse conceptions of fundamental rights capitulated by groups with standardized orientations and behaviors, whose objective prevails, by vertical imposition, on the entire legal system, already including the fundamental rights themselves." (HAEBERLIN, 2017, p. 291)

The exposure of this litigation between "political participation" and "egotopy", it is noted, ends up dismantling some antidemocratic positions. Among them, the two totalizing root doctrines that permeate political participation: communism and liberalism. None of them, in the end, make political participation their ally.

\section{CONCLUSION}

The purpose of the present text was to present political participation as a constitutional right, which was to characterize it from principles and rules, differentiating it from ideologies. This differentiation is based on the normative content of political participation in its power to bind constitutionally. Ideologies are orientations, not law.

The de-ideologization of law is a defense of the people. From what? First, from the classic totalitarian models, which have knocked at the door of Latin American countries, sometimes getting in. Second, from contemporary totalitarian models. In these, we must be attentive to the fact that the mechanisms of adaptation, simple and stealthy, in biological orders, are also in social orders. Although the possibility of resurrection of classic autocracies is diminished due to redemocratizations produced after the war, care must be taken that the antidote to violence - the principles that form the fundamental rights - does not become its own poison.

One of the ways, perhaps the only way, of producing a new totalitarianism is in the endorsement of conceptions of human and fundamental rights which, denying their content within the legal-normative system, make them serve ideologies, especially when, with the pretext of "curing" the state of their diseases (economic, cultural, social, linguistic up to preconceptions), serve a tyranny of groups associated with power projects that dogmatically and vertically impose their objectives. 
In these cases, a dangerous "ideology of human rights" emerges which imposes on man, as if displaying him the showcase of his conquests, the reverse of the product of his conquests. It imposes, as if it were part of the human rights discourse, the dissection of the most material and rigid constant element in a Constitution, which are those rights. Ideologies, as a rule, are friends of the alternative "law found in the street" in the same proportion as they are enemies of the law found in the Constitution.

An enigmatic verse by Hölderlin, quoted by Martin Heidegger (1961) in his research on technique must be noted: "There, where the danger grows, so does the saving power." Perhaps these verses, considering the problem analyzed here, deserve a rearrangement, to say: There, where the saving power grows, so does the danger.

We were rescued out of the abyss by human and fundamental rights. It lies in the obtuse conception of those rights, still, the danger of buying, as a joint sale, an ideology that is passed on as its by-product.

Surely, there will be those who, in criticism, say that the de-ideologization of political participation defended here is nothing more than a search to propagate one ideology instead of another. This criticism holds a serious misunderstanding: the purpose of this article is not to sound a requiem of an ideology or ideologies, nor to raise the flag of any other. What is being proclaimed is simply that ideologies do exist and, should be put in the right place, which is the constitutional policy,and then, to remove them from constitutional interpretation, space where they are inhospitable visitors. What is meant, in short, is that ideologies should be allowedin through the "front ladder" of the Constitution, not deviously, by the "rear ladder" (WISCHEDEL, 1973), where the intangible control of judicial decisions by its motivation, the owner of the house in our metaphor, is not allowed to notice them.

Political participation, as a right conformed by legal norms that align the discursive logic of fundamental rights in the Constitution of contemporary Democratic States, is a fundamental construct of those States. This co-management only exists in a constitutional approach which departs from innate egotopia to ideological conceptions.

It is a delicate matter, for which the whirlwind of political events which have taken place recently in Latin America imposes due and tireless vigil to the jurist who decides to set himself free from his shackles and strive against alienation. 


\section{REFERÊNCIAS}

ARENDT, Hannah. The Origins of Totalitarism. $2^{\mathrm{a}}$ ed. Cleveland: The World Publishing Company, 1962. <https://archive.org/stream/originsoftotalit00aren\#pa ge/n7/mode/2up >.Acessoem: 10 ago. 2018.

BORK, Robert. The original understanding. In: BRISON, Susan e SINNOTARMSTRONG (org.). Contemporary Perspectives on Constitutional Interpretation. Boulder: Westview Press, 1993.

BRUGGER, Winfried; KIRSTE, Stephan; ANDERHEIDEN, Michael (org.). Gemeinwohl in Deutschland, Europa und der Welt. InterdisziplinäreStudienzuRecht und Staat, n. 24. Baden-Baden: Nomos, 2002.

CHAUÍ, Marilena. O que é ideologia. São Paulo: Abril Cultural/Brasiliense, 1984.

COLEMAN, Jules; LEITER, Brian. Legal Positivism. In: PATTERSON, Dennis (ed.). A Companion to Philosophy of Law and Legal Theory. Oxford: Blackwell, 1999.

ENGELS, Friedrich Engels. Ludwig Feuerbach und der Ausgang der deutschen Philosophie. 1845.<http://www.mlwerke.de/me/me03/me03_533.htm>.Acessoem: 10 ago. 2018.

FREIRE, Paulo. Pedagogia da Autonomia: saberesnecessários à práticaeducativa. 24ํㅡㄹ. ed. São Paulo: Paz e Terra, 2002.

GARGARELLA, Roberto. Constitucionalismolatino-americano: a necessidadeprioritária de umareformapolítica. In RIBAS, Luiz Otavio.

ConstituinteExclusiva: um outro Sistema politico é possível. São Paulo: Expressão Popular, 2014.

GIDDENS, Anthony. Beyond Left and Right: The Future of Radical Politics. Stanford: Stanford California Press, 1994.

GRIMM, Dieter Grimm. Die Zukunft der Verfassung. Frankfurt am Main: Suhrkamp, 1991.

HAEBERLIN, Mártin. Uma Teoria do Interesse Público: fundamentos do Estado Meritocrático de Direito. Porto Alegre: Livraria do Advogado, 2017.

HEIDEGGER, Martin. Die Fragenach der Technik. In: Die Technik und die Kehre. Stuttgart: Klett-Cotta, 1962.

HOOVER, Jeffrey; ROBINSON, Scott. "Retaliatory mafia behavior by a parasitic cowbird favors host acceptance of parasitic eggs". In:PNAS - Proceedings of the National Academy of Science of the United States of America. Vol. 104, n. 11, p. 4479-4483. Março 2007. <http://www.pnas.org/content/104/11/4479.full.pdf>.Acessoem: 10 ago. 2018. 
ISENSEE, Josef. Das Volk alsGrund der Verfassung: Mythos und Relevanz der Lehre von der verfassungsgebendenGewalt. Berlin: Springer, 1995.

LYRA FILHO, Roberto. NormasJurídicas e outrasnormassociais. In: SOUSA JR., José Geraldo de (org.). O direitoachadonarua: introduçãocríticaao Direito. 4를 ed. Brasília: Editora da Universidade de Brasília, 1993.

MARX, Karl e ENGELS, Friedrich. Manifesto do Partido Comunista. Translated byCASSAL, SueliTomazini Barros. Porto Alegre: L\&PM, 2002.

MAXIMILIANO, Carlos. Hermenêutica e Aplicação do Direito. 19ª ed. Rio de Janeiro: Forense, 2005.

MONTAIGNE, Michel de. Les Essays. Livro III, 1565.

<http://www.cfh.ufsc.br/ conte/montaigne-essais-III.pdf>.Acessoem: 10 ago. 2018.

NIETZSCHE, Friedrich. Vontade de Potência. Translated by Mário Ferreira Santos. Rio de Janeiro: Ediou, s.d.

POPPER, Karl. A sociedadeaberta e seusinimigos. 3aㅡ. ed. Belo Horizonte: Itatiaia, 1987.

RAWLS, John. A Theory of Justice. Oxford: Oxford University Press, 1999.

RAWLS, John. Political Liberalism. New York: Columbia University Press, 1996.

RICOEUR, Paul. Interpretação e Ideologias. Translated by JAPIASSU, Hilton. Rio de Janeiro: Francisco Alves, 1977.

SEVERINO, Antonio Joaquim. Educação, Ideologia e Contra-ideologia. São Paulo, EPU, 1986.

SUNSTEIN, Cass. The Partial Constitution. Harvard: Harvard University Press, 1993.

TRIBE, Laurence e DORF, Michael. On reading the Constitution. Cambridge: Harvard University Press, 1991.

WEISCHEDEL, Wilhelm. Die philosophischeHintertreppe: 34 großePhilosophen in Alltag und Denken. 1973.<http://www.wehavephotoshop.com/PHILOSOPHY\% 20NOW/PHILOSOPHY/Nachschlagewerke/Weischedel\%20\%20Die\%20philosophische\% 20Hintertreppe.pdf>.Acessoem: 10 ago. 2018. 